\title{
The Effect of Scientific Learning with Video Media on Students' Understanding of Animal Adjustment to Their Environment
}

\author{
Rendra Sakbana Kusuma, Zainal Arifin \\ STKIP PGRI Bangkalan \\ rendra@stkippgri-bkl.ac.id, zainal@stkippgri-bkl.ac.id
}

Article History $\quad$ Received : September $17^{\text {th }} 2021$

Revision : November $11^{\text {th }} 2021$

Publication : December 30th 2021

\begin{abstract}
Science learning in elementary schools has the aim of introducing students to nature and the surrounding environment and being able to understand the role of students in environmental conservation. Science consists of various science theories and through real learning students are able to understand these theories. So far, the implementation of science learning in elementary schools is still using conventional learning models through lectures, questions and answers, and assignments. In learning science, teachers tend to use image media in elementary school science textbooks. Learning that is more dominated by teachers causes students to become passive so that students' understanding of science material is low. To overcome these problems, teachers need to innovate in order to be able to improve the quality of science learning. One of the innovations that can be done by teachers is using a scientific approach in science learning and utilizing video as a science learning medium. The purpose of this study was to prove the effect of scientific learning with video media on students' understanding of the adaptation of animals to their environment. The researcher uses a quantitative research approach because the data generated is in the form of numbers and analyzed statistically. This research is an experimental research and a one group pretest-posttest research design. The population and sample of this study were students of class $\mathrm{V}$ with a total of 23 students. The instrument used to collect research data was a test sheet to measure students' understanding of the adaptation of animals to their environment. By using a paired sample $t$ test analysis through SPSS 21, it was concluded that there was an effect of scientific learning with video media on students' understanding of the adaptation of animals to their environment.
\end{abstract}

Keywords: Scientific Learning, Video Media, Animal Adjustment to Their Environment 


\section{INTRODUCTION}

Education in Indonesia functions as a means of developing Indonesian human resources who are intelligent and have the character of Pancasila and have competitiveness in technological developments and globalization. Education is carried out in stages from elementary to higher education. Educational programs are arranged through a curriculum that is able to provide various competencies for students in dealing with current and future demands and challenges. The laying of the foundations of education is given to the basic education program or primary school. As the main foundation of education, the foundation of education at the elementary level must be strong because it is a material for continuing higher education. Education in elementary schools is the first door for students to know education. Education and learning are carried out by meeting national education standards so that they are able to support the achievement of national education goals. Teachers are at the forefront of providing education and learning in primary schools. Quality teachers will be able to provide quality education and learning in primary schools. Therefore, teachers must have four main competencies, namely pedagogical, professional, personal, and social competencies. Pedagogical competence is related to teacher competence in managing learning so that teachers are expected to have innovation and creativity in carrying out active, fun, and meaningful learning for students.

The implementation of learning in elementary schools has various obstacles, especially in science learning which consists of many theories, but these theories must be proven through the science learning process. The selection of learning models and media that are not suitable will hinder the achievement of learning objectives. Researchers observed science learning in class V UPTD SDN Gili Timur 1 Kamal and found science learning still using conventional learning models through lectures, questions and answers, and giving learning assignments. Learning is dominated by the teacher so that students are not actively involved during the learning activities. The media used is the image media contained in the school package book. This condition causes students' understanding of science subject matter to be low so that students' science learning outcomes are also low. Of the 23 students, only 10 students were able to fulfill the KKM and the rest obtained test scores below the KKM. Scientific learning is expected to be able to increase student activity in the learning process and accompanied by the use of video learning media is expected to provide convenience for students in understanding science subject matter in elementary schools. Based on the above background, the researchers determined that the research objective was to determine the effect of scientific learning with video learning media on students' understanding of the adaptation of animals to their environment. 


\section{LITERATURE REVIEW}

\section{Scientific Learning}

The 2013 curriculum emphasizes the achievement of competencies. The learning uses scientific and involves students to learn. Student involvement will encourage their interest in learning activities (Sari et al, 2019:320). The scientific approach is the approach used in the 2013 curriculum and is a development of the various curricula that underlie the previous ones. The 2013 curriculum was developed based on global needs and challenges as well as the world of work. Learning in the 2013 curriculum is directed at mastering various competencies, including the competence of spiritual attitudes, social attitudes, knowledge, and skills. The 2013 curriculum is a curriculum that prioritizes student involvement in learning activities. Students are individuals who learn so that learning approaches and models are expected to encourage students to be more active in learning.

The scientific approach is a learning process approach that provides opportunities for students to actively construct concepts, laws or principles with activities in the form of observing, asking, reasoning, associating and communicating (Hosnan in Meilani et al, 2020: 2). Science learning using a scientific approach is expected to improve students' science process skills. Students' science learning outcomes are a series with the learning process so that the process of students' science skills is a supporting force for achieving science learning objectives so as to obtain maximum learning outcomes. Science learning process activities that use a scientific approach in the form of student learning activities which include observing, questioning, reasoning, associating and communicating activities.

Abidin in Asyhari and Hartati (2015: 183) explains the steps of scientific learning which consist of 1) observing, 2) asking questions, 3) extracting information, 4) reasoning, and 5) communicating. In detail, science learning activities on the material adaptation of animals to their environment are as follows:

a. Observe

Students observe science learning videos about the adaptation of animals to their environment

b. Asking question

Students ask questions related to the adaptation of animals to their environment. Teachers and students can provide responses to questions asked by students.

c. Doing information mining

Students explore references by reading learning resources from books and other sources.

d. Reasoning

Based on the results of extracting information, students learn to reason and understand learning topics about the adaptation of animals to their environment.

e. Communicate 
Students' understanding of the material adaptation of animals to their environment is communicated to other students in the class.

\section{Learning Video Media}

The learning process is a system consisting of several interconnected and mutually influencing sub-systems including: (1) Students, (2) Teachers, (3) Learning media, (4) Learning methods, (5) Learning objectives, (6) Learning resources, (7) Facilities and infrastructure, (8) Environment. If one of the subsystems is not optimal, then the success of the learning process will also not be optimal (Hadi, 2019:97). Video learning is an aspect that greatly affects the learning process in addition to other aspects. learning media serves to make it easier for teachers to convey learning information and make it easier for students to understand the information conveyed by the teacher. Learning media becomes more effective if it is able to accommodate all types or styles of student learning so that the media is expected to have visual, audio, and kinesthetic aspects. Referring to these criteria, video is an effective learning medium in achieving the objectives of science learning for animals adapting to their environment. Video is an effective medium used to improve the ability of elementary school students in understanding concepts (Hadi, 2019:99).

\section{Adaptation of Animals to their Environment}

Dianingrum (2012: 212-2016 explains the material and examples of animal adaptation to their environment are described as follows:

\section{Animals adapted for obtaining food}

\section{a. Bird}

Birds have different foot shapes depending on where they live and the type of prey they eat. Based on the environment and the type of food they eat, the shape of the feet of birds are grouped into five, namely the shape of the feet of pedestrians, swimmers, predators, climbers, and petenggers. Different types of birds and fowl have different beak shapes. These differences indicate a form of adaptation of animals to the type of food. The shape of the beak of birds is also diverse, the diversity of the shape of the beak of birds according to the type of food such as eagles, sparrows, woodpeckers, and chickens.

b. Insect

To get their food, insects have their own way. One form of adaptation is the shape of the mouth that varies according to the type of food. Based on the type of food they eat, insect mouths are divided into four, namely sucking mouths, piercing mouths, licking mouths, and absorbent mouths.

1) Sucking mouth. The sucker mouth of insects is shaped like a proboscis that can be rolled up and stretched out. An example of an insect that has a sucking mouth is a butterfly. Butterflies use sucker mouths to suck nectar from flowers. Nectar is a sweet liquid in plants as an ingredient for making honey. Nectar is located at the base of the flower. Because of the location of the nectar at the base of the flower and in liquid form, to obtain it, the butterfly has a long 
sucker. The long sucker makes it easier for the butterfly to suck the nectar. This sucking apparatus is called the proboscis.

2) Piercing and sucking mouths. The piercing and sucking mouths of insects are characterized by sharp and long shapes. An example of an insect that has a piercing and sucking mouth is the mosquito. Mosquitoes use their mouths to pierce human skin and then suck blood. So, in addition to the mouth that functions as an awl, it also functions as a sucker.

3) Licking mouth. The licking mouth of insects is characterized by the presence of a long tongue and is useful for licking food in the form of nectar from flowers, an example of an insect that has a licking mouth is a bee.

4) Absorbent mouth. The absorbent mouth of insects is characterized by the presence of a sponge-like absorbent device (cork). This tool is used to absorb food, especially in liquid form. An example of an insect that has an absorbing mouth is a fly.

c. Camel

Camels have humps on their bodies. Camels live in dry, hot and arid desert areas. The existence of the hump is used to store food reserves. If it does not get food, the camel's body will use the food reserves naturally. Camels are also able to drink large amounts of water and are stored as body fluids. Thus, the camel can survive despite the lack of food and water for a long time2) Animal Adaptation to Enemy Attacks Apart from adapting to how to obtain food, animals also adapt to enemy attacks. This is done so that the animal can survive. Some animals adapt to enemy attacks by using their bodies. Meanwhile, some other animals protect themselves from attacks. There are several types of animals that adapt to their environment by changing their behavior. This method is not only to get food but also to protect themselves from enemies or predators.

\section{Animals that adapt to behavior}

a. Chameleon. Chameleons usually live in trees. However, the presence of chameleons is often not noticed by the enemy because the color of the chameleon's skin can change according to the color of the environment. Several factors influence this change in skin color, namely light, temperature and the chameleon's reflexes to its surroundings. The most common discoloration is green, brown or gray. This ability can protect and prevent chameleons from their enemies.

b. Walang Sangit. Walang sangit is known as a rice pest. This animal protects itself from enemies by emitting a very strong odor so that the enemy stays away from it.

c. Walang Leaves. Walang leaves has a body shape and color that resembles a leaf. This state of the body is very beneficial for the leafhopper. Leaf bugs live on plants whose leaf shape and color are very similar to the leaf bug's body. This will make it difficult for the enemy to find out the existence of the leafhopper.

d. Tigers, Dogs, and Lions. These animals have sharp claws and teeth. The sharp nails and teeth are useful for protecting himself. If there is an enemy or prey that comes, they will attack with their sharp claws and teeth.

e. Cows, Goats, Buffaloes and Deer. Cows, goats, buffalo, and deer have pointed horns. These animals use their horns when fighting with enemies. 
f. Scorpions, centipedes, and bees. Scorpions, centipedes, and bees use their stingers to protect themselves from enemies. These animals can emit toxic substances to the enemy through their sting. This poison is used to kill enemies.

g. Snake. There are two types of snakes, namely venomous snakes and nonvenomous snakes. Venomous snakes are snakes that have poisonous substances for enemies. The substance is called venom, which is produced by a gland. Snakes can be used to kill enemies. When a snake bites an enemy, it can flow through the snake's teeth into the enemy's body. The bite of a venomous snake can result in death for the enemy. An example of a venomous snake is the cobra. Non-venomous snakes protect themselves by wrapping their bodies around the enemy's body. The entanglement of a very strong snake can also result in death for the enemy. An example of a non-venomous snake is a python.

h. Squid. Squid live in water. Squid protect themselves from enemies by spraying a liquid like ink into the water. So the enemy can't see it. At that moment, the squid swims fast to avoid its enemy.

i. Snail. Snails have a hard body armor commonly called a cochlea. This animal protects itself from enemies by inserting its body into its house.

j. Weasel and beetle. Weasels and beetles pretend to be dead when attacked by enemies. If the enemy was gone, they immediately went elsewhere.

k. gecko. Geckos have a unique form of self-protection. If the lizard's tail is grabbed by the enemy, then the tail is released from its body. The enemy only got the loose tail, while the lizard immediately ran away. On the part of the body that was severed it would grow a new tail.

1. Whales. Whales are mammals that live in water. Like other mammals, although living in water, whales breathe using lungs. Though the lungs can not take oxygen from the water. Whales and all mammals that live in water, about every thirty minutes come to the surface of the water to breathe oxygen. Maybe you have seen how whales behave on television. When it comes to the surface of the sea, whales expel the rest of their breathing in the form of carbon dioxide and water vapor which is saturated with water so that it looks like a fountain. After that the whale inhaled as much air as possible so that its lungs filled with air.

\section{METHODS}

\section{Approaches and types of research}

There are various approaches that can be used in conducting research. In this study, the researcher used a quantitative research approach to find a correlation or relationship between the use of animated picture media and understanding the concept of elementary school students' mathematical fractions. Quantitative research is research that is based on the philosophy of positivism, used to examine certain populations or samples, data collection using research instruments, statistical data analysis, with the aim of testing established hypotheses (Sugiyono, 2014:8). The stages of implementing quantitative research have clear and systematic patterns or stages. 
Quantitative research has various types of research based on research needs and objectives. In this case, the researcher chose the type of experimental research, where the researcher correlated the data on understanding mathematical concepts of students who had not received new treatment, namely using animated images, and students who had received new treatment. The researcher used a pre-experimental design experimental research form with a onegroup pretest-posttest design model.

\section{Population and Sample}

Characteristics of quantitative research is that there is a population and research sample. The presence of the population and sample is an absolute requirement in quantitative research where the results of research on the sample can be generalized to the entire population if the sampling is in accordance with applicable regulations. The population is a generalization area consisting of objects/subjects that have certain qualities and characteristics determined by researchers to be studied and then drawn conclusions (Sugiyono, 2014:80). While the sample is part of the number and characteristics possessed by the population (Sugiyono, 2014:9).

The population in this study were 23 students of class V UPTD SDN Gili Timur I Kamal. considering the number of population is not too much, the researchers used a saturated sample selection technique to select all members of the population as a sample. Saturated sampling is a sampling technique when all members of the population are used as samples (Sugiyono, 2014:85).

\section{Data Collection Methods and Instruments}

To obtain data on the effect of scientific learning with video media on students' understanding of the adaptation of animals to their environment, researchers used methods and instruments that were relevant to the research objectives. The researcher used the test method with the research instrument in the form of a test question sheet consisting of 10 multiple choice questions and 10 description questions. The research instrument before being used was tested for validity and reliability.

\section{Data analysis}

The next step after collecting data using test methods and instruments is data analysis based on the problem formulation that has been stated previously. Based on the problem formulation, the researcher used paired sample t test analysis. If the results of the analysis using the paired sample t test are less than 0.05 , it can be concluded that there is an effect of scientific learning with video learning media on students' understanding of the adaptation of animals to their environment. 


\section{RESULTS AND DISCUSSION}

The data generated during this research process uses a data collection instrument in the form of test questions that have gone through the stages of validity and reliability testing. Validity and reliability tests were carried out by performing statistical analysis using SPSS 21. Researchers tested the instrument on 10 students and then the data was analyzed for validity and reliability using SPSS 21. From the results of the analysis, the $r$ value was obtained above 0.444 for the number of test samples 23 students. based on the results of the analysis, it can be stated that the test instrument consists of 10 multiple choice questions and 10 valid and reliable questions. After the research instrument was declared valid and reliable, the researchers used the instrument to collect pretest and posttest data on students' understanding of the adaptation of animals to their environment.

Researchers used pretest and posttest data on students' understanding of the adaptation of animals to their environment to determine the effect of thematic learning with video media on students' understanding of animal adaptation to their environment. The pretest and posttest data were then analyzed using paired sample t test analysis with SPSS 21 to determine the results of the analysis in achieving the research objectives. Analysis of Paired Sample T Test is described as follows:

\begin{tabular}{|c|c|c|c|c|c|}
\hline \multicolumn{6}{|c|}{ Paired Samples Statistics } \\
\hline & & Mean & $\mathrm{N}$ & Std. Deviation & Std. Error Mean \\
\hline \multirow{2}{*}{ Pair 1} & $\begin{array}{l}\text { PRETEST STUDENT'S } \\
\text { UNDERSTANDING }\end{array}$ & 70.1304 & 23 & 26.34786 & 5.49391 \\
\hline & $\begin{array}{l}\text { POSTTEST STUDENT'S } \\
\text { UNDERSTANDING }\end{array}$ & 88.8261 & 23 & 11.82314 & 2.46529 \\
\hline
\end{tabular}

\begin{tabular}{|ll|r|r|r|}
\hline \multicolumn{2}{|c|}{ Paired Samples Correlations } \\
\hline \multirow{2}{*}{ Pair 1 } & \multicolumn{1}{|c|}{$\mathrm{N}$} & Correlation & \multicolumn{1}{c|}{ Sig. } \\
\hline
\end{tabular}

\begin{tabular}{|c|c|c|c|c|c|}
\hline \multicolumn{6}{|c|}{ Paired Samples Test } \\
\hline & & \multicolumn{4}{|c|}{ Paired Differences } \\
\hline & & \multirow[t]{2}{*}{ Mean } & \multirow[t]{2}{*}{ Std. Deviation } & \multirow[t]{2}{*}{ Std. Error Mean } & $\begin{array}{l}95 \% \text { Confidence } \\
\text { Interval of the } \\
\text { Difference } \\
\end{array}$ \\
\hline & & & & & Lower \\
\hline Pair 1 & $\begin{array}{l}\text { PRETEST STUDENT'S } \\
\text { UNDERSTANDING - POSTTEST } \\
\text { STUDENT'S UNDERSTANDING }\end{array}$ & -18.69565 & 15.59264 & 3.25129 & -25.43842 \\
\hline
\end{tabular}

\begin{tabular}{|c|c|c|c|c|c|}
\hline \multicolumn{6}{|c|}{ Paired Samples Test } \\
\hline & & Paired Differences & \multirow[t]{3}{*}{$\mathrm{t}$} & \multirow[t]{3}{*}{$\mathrm{df}$} & \multirow[t]{3}{*}{ Sig. (2-tailed) } \\
\hline & & $\begin{array}{l}\text { 95\% Confidence } \\
\text { Interval of the } \\
\text { Difference }\end{array}$ & & & \\
\hline & & Upper & & & \\
\hline Pair 1 & $\begin{array}{l}\text { PRETEST STUDENT'S } \\
\text { UNDERSTANDING - POSTTEST } \\
\text { STUDENT'S UNDERSTANDING }\end{array}$ & -11.95289 & -5.750 & 22 & .000 \\
\hline
\end{tabular}


The results of the paired sample test analysis of 23 research samples using pretest and posttest data obtained sig values. (2-tailed) is smaller than 0.05 so the researcher concludes that there is an effect of scientific learning with video learning media on students' understanding of the adaptation of animals to their environment.

\section{CONCLUSION}

Based on the results of the statistical analysis described in the previous chapter, the researcher concludes that there is an effect of scientific learning with video learning media on students' understanding of the adaptation of animals to their environment.

\section{BIBLIOGRAPHY}

Asyhari, A, dan Hartati, R. (2015). Profil Peningkatan Kemampuan Literasi Sains Siswa Melalui Pembelajaran Saintifik, Jurnal Ilmiah Pendidikan Fisika, 4(2): 179-191.

Dianingrum, N. (2012). Upaya Meningkatkan Hasil Belajar Sains/IPA Pada Konsep Penyesuaian Diri Makhluk Hidup Dengan Menggunakan Pendekatan Quantum Learning, Jurnal Primary, 4(2): 203-221.

Hadi, S. (2017). Efektivitas Penggunaan Video Sebagai Media Pembelajaran Untuk Siswa Sekolah Dasar, disampaikan pada Seminar Nasional dengan Tema Transformasi Pendidikan Abad 21 pada bulan Mei Tahun 2017.

Meilani, D, Dantes, N, dan Tika, I, N. (2020). Pengaruh Implementasi Pembelajaran Saintifik Berbasis Keterampilan Belajar Dan Berinovasi 4C Terhadap Hasil Belajar IPA Dengan Kovariabel Sikap Ilmiah Pada Peserta Didik Kelas V SD Gugus 15 Kecamatan Buleleng, Jurnal Elementary: Kajian Teori dan Hasil Penelitian Pendidikan Sekolah Dasar, 3(1): 1-5.

Sari, P, O, W, Wardani, N, S, dan Prasetyo, T. (2019). Pengaruh Pembelajaran Saintifik Example Non Example Terhadap Minat Belajar, Jurnal Ilmiah Sekolah Dasar, 3(3): 319-325.

Sugiyono. (2014). Metode Penelitian Kuantitatif Kualitatif dan R\&D, Bandung: Alfabeta 